\title{
Pelagic-benthic coupling on the shelf of the northern Bering and Chukchi Seas. III. Benthic food supply and carbon cycling
}

\author{
Jacqueline M. Grebmeier*, C. Peter McRoy \\ Institute of Marine Science, University of Alaska Fairbanks, Fairbanks, Alaska 99775-1080, USA
}

\begin{abstract}
Benthic carbon cycling in the northern Bering and Chukchi Seas was hypothesized to be regulated by variable primary production regimes in the overlying water: the highly productive $(\sim 250$ to $300 \mathrm{~g} \mathrm{C} \mathrm{m}^{-2} \mathrm{yr}^{-1}$ ) Bering Shelf-Anadyr Water (BSAW) and the less productive $\left(\sim 50 \mathrm{~g} \mathrm{C} \mathrm{m}^{-2} \mathrm{yr}^{-1}\right.$ ) Alaska Coastal Water (ACW). Sediment oxygen uptake was correlated with water column parameters and surface sediment $\mathrm{C} / \mathrm{N}$ ratios characteristic of each water type. Total sediment oxygen uptake rates decreased from a mean $19.2 \mathrm{mmol} \mathrm{O} \mathrm{m}^{-2} \mathrm{~d}^{-1}$ in BSAW to a mean $8.7 \mathrm{mmol} \mathrm{O}_{2} \mathrm{~m}^{-2} \mathrm{~d}^{-1}$ in $\mathrm{ACW}$. Mean benthic aerobic respiration rates significantly varied interannually in BSAW, although they were consistently 2 to 3 times greater in BSAW than in ACW within any one year, indicating that interannual variability in water column primary production may have a direct influence on the availability of organic carbon to the benthos. The explanation for higher respiration rates in the benthos beneath BSAW negates an expected reduction due to colder temperatures. A reduction in organic matter to the benthos in ACW apparently limits benthic metabolism even at higher temperatures. Macrofaunal respiration and bioturbation in high benthic biomass regions were important components in benthic carbon cycling.
\end{abstract}

\section{INTRODUCTION}

Past studies have shown a direct relationship between particulate organic matter flux to the benthos and planktonic production in the surface waters of the ocean (Eppley \& Peterson 1979, Deuser et al. 1981, Davies \& Payne 1984). The quantity and quality of freshly produced or repackaged organic carbon reaching the benthos is influenced by many factors, such as mixed layer and water column depth, zooplankton grazing and bacterial decomposition in the water column (Parsons et al. 1977). Supply of organic matter to the benthos is a major factor influencing benthic community structure, biomass and metabolism (Mills 1975 . Graf et al. 1982, Jørgensen 1983, Smith et al. 1983, Smetacek 1984, Wassman 1984, Grebmeier 1987. Grebmeier et al. 1988, 1989).

In this study, we used sediment oxygen uptake rate as an indicator of variability in the supply of organic

\footnotetext{
- Address for correspondence: Graduate Program in Ecology, University of Tennessee, Knoxville, Tennessee 37996-1610. USA
}

carbon to the benthos. We hypothesized that total sediment oxygen uptake would reflect major differences in overlying water column production. Surface sediment $\mathrm{C} / \mathrm{N}$ ratios are used as an indicator of food quality and, thus, the highest sediment oxygen uptake would reflect areas of increased supply of high quality (low $\mathrm{C}$ / $\mathrm{N}$ ratio) phytodetritus to the benthos. An ancillary hypothesis was that in regions of high benthic populations, organic carbon turnover in the sediments would be enhanced by increased bioturbation by the dominant fauna. X-radiography of sediment cores, vertical profiles of sediment $\mathrm{C} / \mathrm{N}$ ratios, and faunal abundance and biomass data are used to investigate potential bioturbation factors. This work was part of an interdisciplinary oceanographic study (ISHTAR: Inner Shelf Transfer and Recycling), which provided supporting data on hydrographic features and water column productivity.

The shallow continental shelf of the northern Bering and Chukchi Seas is characterized by water depths averaging less than $50 \mathrm{~m}$ and is ice-covered 7 to $8 \mathrm{mo}$ of the year. Northerly-flowing currents transport Bering Sea water through the Bering Strait and across the shelf in the Chukchi Sea (Fig. 1). The summer season physi- 


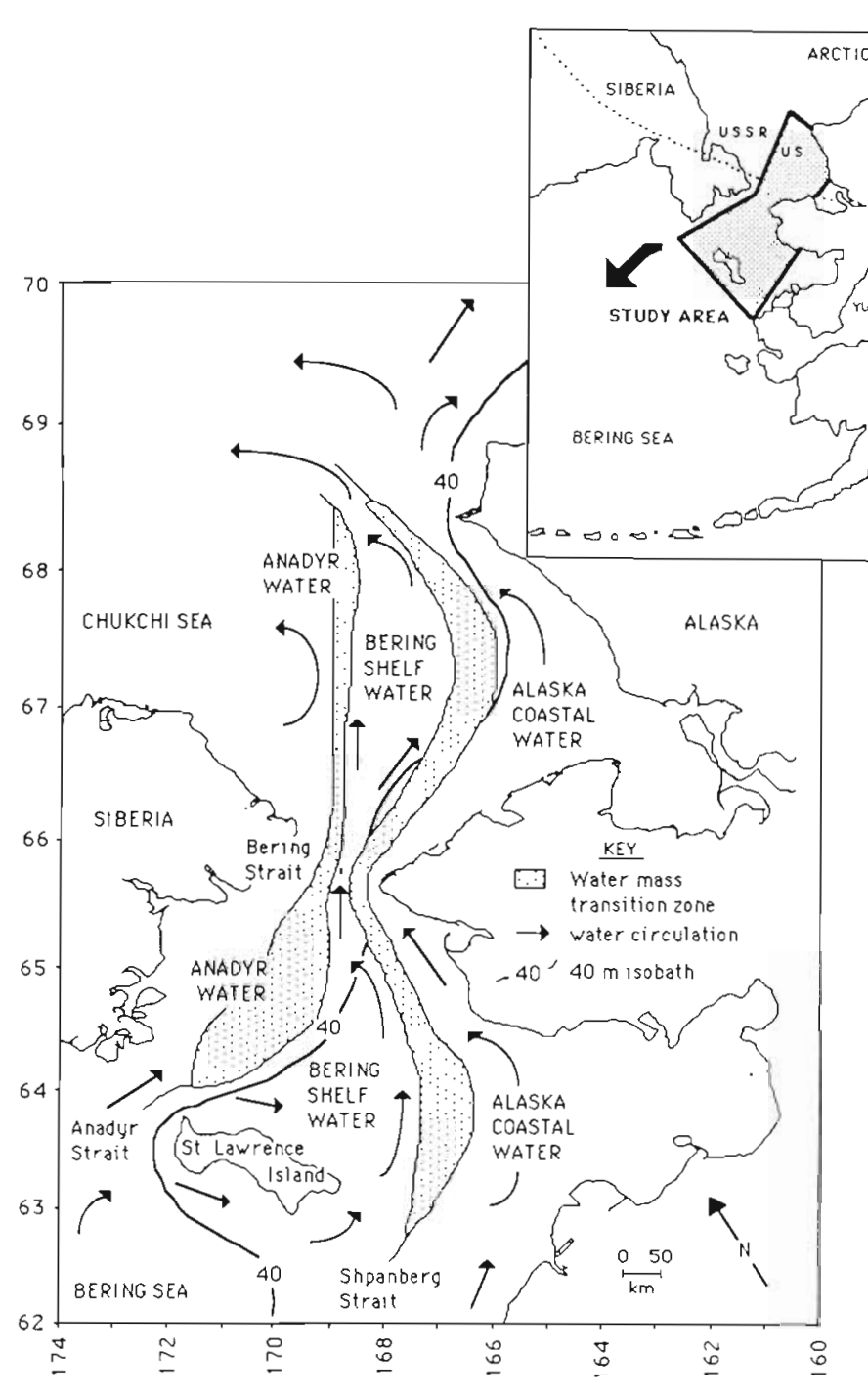

cal oceanographic regime in the area includes 3 water masses defined by T/S profiles (Coachman et al. 1975, Schumacher et al. 1983, Coachman 1987). During the 1985 and 1986 summer season the following bottom water properties characterized these water masses: Anadyr Water ( $\mathrm{S} \geq 32.5 \%, \mathrm{~T}=-1.0$ to $\left.1.5^{\circ} \mathrm{C}\right)$ on the western side of the system, Bering Shelf Water ( $\mathrm{S}=$ $31.8-32.5 \%, T=0$ to $1.5{ }^{\circ} \mathrm{C}$ ) in the middle region, and Alaska Coastal Water (ACW; S $\leq 31.8 \%$, T $\geq 4{ }^{\circ} \mathrm{C}$ ) near the Alaska coast (Coachman 1987). The Bering Shelf and Alaska Coastal waters form a well-defined frontal zone where they meet. However, the interface between Anadyr and Bering Shelf waters is less distinct and forms a more gradual gradient from east to west. Since the salinity, temperature, and nutrient signature of this central water is a combination of both Anadyr and Bering Shelf waters, the combined water hereafter is designated as the Bering Shelf-Anadyr Water (BSAW). The tidal range in the study area is small ca
Fig. 1. Study area in the northern Bering and Chukchi Seas showing local water circulation, water masses, and bathymetry (modified from Coachman et al. 1975 and Coachman 1987)

5 to $10 \mathrm{~cm}$ (Pearson et al. 1981, Kowalik \& Matthews 1982).

High primary and secondary productivity characterize the northern Bering and Chukchi Seas in BSAW (McRoy et al. 1972, Stoker 1978, 1981, Grebmeier et al. 1988, Springer 1988, Walsh et al. 1988, Walsh et al. 1989). Estimated annual primary production in BSAW is 250 to $300 \mathrm{~g} \mathrm{C} \mathrm{m}^{-2}$ compared to an estimated annual primary production of $50 \mathrm{~g} \mathrm{C} \mathrm{m}^{-2}$ in ACW (Sambrotto et al. 1984, Springer 1988, Walsh et al. 1989). Benthic biomass averages $20 \mathrm{~g} \mathrm{C} \mathrm{m}^{-2}$ in BSAW, where amphipod and bivalve populations are dominant, and decreases to $6 \mathrm{~g} \mathrm{C} \mathrm{m}^{-2}$ in $\mathrm{ACW}$, where a diverse fauna of amphipods, polychaetes and bivalves occur (Grebmeier 1987. Grebmeier et al. 1988, 1989).

Sediment oxygen uptake rates can provide information on aerobic utilization of organic carbon in sediments and have been shown to increase with increased carbon flux to sediments (Hargrave 1969, 1973, Davies 1975, Pamatmat 1977, Deuser \& Ross 1980, Suess 1980, Nixon 1981, Smith et al. 1983, Davies \& Payne 1984). Although useful in estimating community metabolism in sediments, oxygen respiration rates underestimate total sediment metabolism since they do not directly measure anaerobic processes (Hargrave 1969, Pamatmat 1971a, b, 1977, Davies 1975, Patching \& Raine 1983), which can be evaluated by measurement of other oxidants, such as nitrate and sulfate. Higher temperature is known to enhance benthic metabolism (Hargrave 1969, 1973, Davies 1975, Pamatmat 1977. Smith 1978, Smith et al. 1983), but temperature is also often correlated to food supply.

The contribution of macrofaunal respiration to total sediment community metabolism varies with faunal abundance, species composition and season (Kemp \& Boyton 1981). Macrofaunal respiration can range from 20 to $90 \%$ of the total community respiration (Smith 1973, Pamatmat 1977, Gray 1981, Blackburn 1987b, Emerson et al. 1988). Blackburn (1987b) found macrofauna could account for up to $70 \%$ of total sediment 
metabolism in the northern Bering and Chukchi Seas. The presence of irrigated burrows and tubes in sediment can cause increased oxygen uptake and nutrient flux between the sediment and overlying water, with benthic faunal bioturbation and irrigation being important exchange processes (Goldhaber et al. 1977, Aller \& Yingst 1978, Aller 1980, Hylleberg \& Henriksen 1980). In addition, bioturbation and irrigation can transport higher organic content surface sediments downwards into the sediment (Fauchald \& Jumars 1979). Some species, such as maldanid polychaetes, transport buried organic carbon to the surface, thus stimulating aerobic heterotrophic microorganisms and organic carbon mineralization (Aller 1980, 1982).

\section{MATERIAL AND METHODS}

Sediment samples were collected using either a HAPS $0.0133 \mathrm{~m}^{2}$ corer or a MK3 $0.25 \mathrm{~m}^{2}$ box corer. A core incubation technique for benthic metabolism determination was used, following methods described in Pamatmat (1971a), Newrkla (1983), and Patching \& Raine (1983). Subsamples for shipboard core incubations were collected with $13 \mathrm{~cm}$ diameter, $26 \mathrm{~cm}$ long PVC and acrylic cores ( $8 \mathrm{~mm}$ thick walls). Average sediment depth in the cores was 10 to $15 \mathrm{~cm}$, with the remainder of the core overlaid with bottom water. Overlying bottom water was carefully siphoned off and replaced with bottom water collected with a Niskin bottle. The cores were sealed with air-tight lids with a battery-operated stirrer inside that mixed the water to reduce oxygen gradient formation without disturbing the sediments (Newrkla 1983). Control laboratory experiments showed no disturbance of the sediment surface by stirring nor leakage of oxygen through the container walls.

Cores were maintained in the dark at 1 to $2^{\circ} \mathrm{C}$ for an average 8 to $10 \mathrm{~h}$. This experimental duration was determined an adequate length for measurable depletion of oxygen (average $25 \%$ ) in the chambers. Oxygen uptake rates, measured in stirred cores for a variety of sediments (both core and in situ methods of measurements) have been found constant for up to $22 \mathrm{~h}$ (Patching \& Raine 1983, Newrkla 1983). Duplicate $60 \mathrm{ml}$ water samples were collected at the beginning of the experiment from the Niskin bottle and from the sediment cores at the end of the experiment for determination of dissolved oxygen content by Winkler titration. On RV 'Alpha Helix' Cruise 59 (30 June to 10 July 1984) a YSI 49 oxygen electrode and meter were used.

Organic carbon mineralization rates were estimated from the sum of known oxidants in the sediments, oxygen and sulfate, since nitrate is relatively minor as an oxidant (H. Blackburn pers. comm.). Sulfate reduc- tion rates were obtained from Blackburn \& Henriksen (1986) and Blackburn (1987a). Organic carbon mineralization rates were corrected for chemical oxidation at stations with high sulfate reduction rates and high levels of free sulfide (H. Blackburn pers. comm.). At these stations $15 \%$ of the measured sediment oxygen uptake rate was subtracted from the original value, based on the assumption that this percentage of oxygen served as a sulfide oxidant and was not available for organic carbon mineralization (Jørgensen 1982, Blackburn \& Henriksen 1986). Oxygen is the major oxidant in sediments in the northern Bering Sea under all water masses (Blackburn 1987b), thus organic carbon mineralization rates for stations without high sulfate reduction rates were based on a direct conversion from oxygen to carbon and a respiratory quotient of 1.0 (Nixon et al. 1980).

Thin-section plexiglas boxes $(2.5 \times 16.0 \times 28.0 \mathrm{~cm})$ were used to sample from the box corer and large $(13.0$ $\mathrm{cm}$ diameter $\times 28.0 \mathrm{~cm}$ length) PVC cores were used to collect sediment from the HAPS corer at representative stations in BSAW and ACW and then frozen. Frozen sediment was extracted from the large cores and cut to 2 to $3 \mathrm{~cm}$ width slabs. Both frozen plexiglas boxes and sediment slabs were $\mathrm{X}$-rayed to illuminate burrow structure. Minimum burrow surface area was determined for a representative core in the highly bioturbated zone of the BSAW by tracing the inside burrow wall area from the $X$-ray onto a piece of paper and then passing the 2-dimensional picture through a LiCore Model 3100 area meter. Once X-rayed, the sediment from the plexiglas boxes and large core slabs were sectioned at 1 to $2 \mathrm{~cm}$ intervals and the fauna encountered were recorded to species level.

Sediments were sectioned at 1 to $2 \mathrm{~cm}$ intervals, dried, and homogenized for organic carbon and nitrogen analyses. Sediments $(1 \mathrm{~g})$ were acidified with $2 \mathrm{ml}$ of $1 \mathrm{~N} \mathrm{HCl}$ and dried at $105^{\circ} \mathrm{C}$ overnight to obtain carbonate-free sediments, and then homogenized. Duplicate measurements of carbon and nitrogen in sediments were made using a Perkin-Elmer Model $240 \mathrm{C}$ CHN elemental analyzer.

Salinity, temperature, and depth data were obtained in conjunction with other investigators using a Niel Brown conductivity-temperature-depth profiler. Data collected as part of the ISHTAR project are available in annual data reports (McRoy \& Tripp 1986, 1987). Water column integrated and bottom chlorophyll a values were also obtained as part of the ISHTAR project and from Grebmeier (1987).

The parametric Pearson's product-moment correlation test was used to investigate correlations between mean oxygen uptake rates and environmental variables. A nonparametric Mann-Whitney $U$-test was performed on the mean oxygen uptake values for stations in 
BSAW and ACW to determine if there was a significant difference in rates between stations in each water type. In addition, a nonparametric Kruskal-Wallis test was used to test for significant differences in oxygen uptake rates between years within BSAW and ACW. A microcomputer statistical package (Brain Power Inc. 1985) was used for these analyses, along with appropriate statistical tables (Rohlf \& Sokal 1969, Conover 1980).

Each station designation presented in subsequent tables is composed of 5 numbers; the first 2 numbers designate the cruise, the second 3 numbers designate the actual station.

\section{RESULTS}

Benthic stations were occupied over 3 field seasons from July to September 1984 to 1986 in the study area. Temperature and salinity data confirmed the presence of a front dividing BSAW and ACW (McRoy \& Tripp $1986,1987)$. This front, which varies in location over the open-water season, separates BSAW and ACW with a salinity boundary of $31.8 \%$ (Coachman 1987). The average location of the front was used to designate station locations relative to BSAW and $\mathrm{ACW}$.

Hydrographic data and sediment oxygen uptake rates were collected at 61 stations in the northern Bering and Chukchi Seas, 45 in BSAW and 16 in ACW, during 5 cruises on the RV 'Alpha Helix' (Fig. 2; Table 1). The cruise dates were as follows: Cruise 59 (30 June to 10 July 1984), Cruise 73 (25 July to 10 August 1985), Cruise 74 (26 August to 9 September 1985), Cruise 85 (11 to 26 July 1986) and Cruise 87 (14 to 24 August 1986).

\section{Oxygen uptake and carbon mineralization rates}

Oxygen uptake rates were measured on duplicate sediment cores for 32 of the 45 stations located in BSAW and 12 of the 16 stations located in $\mathrm{ACW}$; the remainder were single core measurements (Table 1 ). Before pooling average duplicate values with individual measurements, a Mann-Whitney test was performed on the data. There was no significant difference between the mean of duplicate measurements and single measurements for stations in either BSAW $(p>$ $0.25)$ or ACW $(p>0.25)$, thus all stations were subsequently included in the analysis.

Sediment oxygen uptake rates averaged $19.18 \mathrm{mmol}$ $\mathrm{O}_{2} \mathrm{~m}^{-2} \mathrm{~d}^{-1}$ in BSAW and $8.72 \mathrm{mmol} \mathrm{O}_{2} \mathrm{~m}^{-2} \mathrm{~d}^{-1}$ in ACW over the total study period (Table 2). Similarly, the mean organic carbon mineralization rate was 2 to 3 times higher in BSAW (20.21 mmol C m $\mathrm{Cd}^{-1}$ ) compared to ACW (9.04 mmol $\mathrm{C} \mathrm{m}^{-2} \mathrm{~d}^{-1}$; Table 2). There

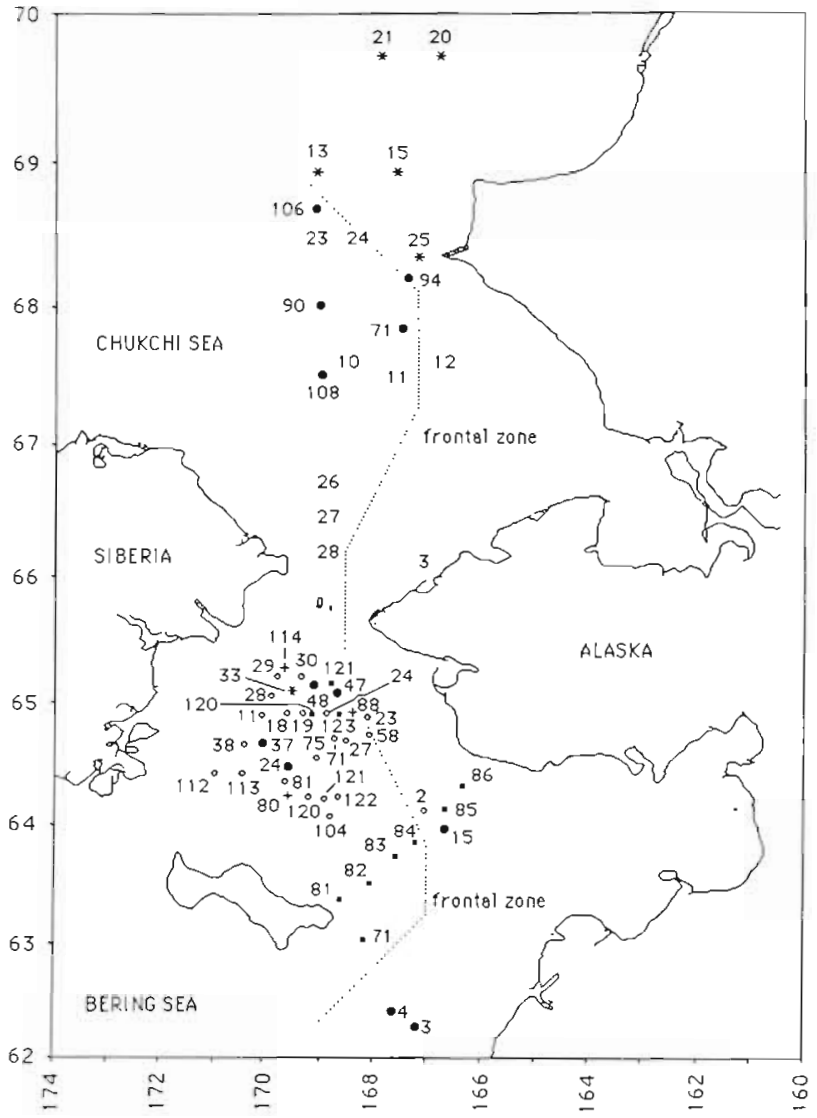

Fig. 2. Location of stations for benthic respiration experiments in the northern Bering and Chukchi Seas for cruises 59 (匹), 73 $(0), 74(*), 85(\bullet)$ and $87(+)$. A frontal zone separates Bering Shelf-Anadyr Water in the west from Alaska Coastal Water in the east

were significant differences between both oxygen uptake and carbon mineralization rates in the 2 water types based on a Mann-Whitney test, stated as a 1 -tailed test, $p<0.001$.

The highest oxygen uptake rates occurred at stations in BSAW, both in the northern Bering and Chukchi Seas (Fig. 3). In the northern Bering Sea high values ( $\geq 30 \mathrm{mmol} \mathrm{O} \mathrm{m}^{-2} \mathrm{~d}^{-1}$ ) were measured northeast of St Lawrence Island and in the central region between St Lawrence Island and Bering Strait, known as the Chirikov Basin. Rates averaged 30 to $40 \mathrm{mmol} \mathrm{O}_{2} \mathrm{~m}^{-2}$ $\mathrm{d}^{-1}$ in the Chirikov Basin and were lowest $(<10 \mathrm{mmol}$ $\mathrm{O}_{2} \mathrm{~m}^{-2} \mathrm{~d}^{-1}$ ) at stations in ACW and in regions of BSAW northwest of St Lawrence Island and north of Bering Strait. Significant interannual variability in sediment oxygen uptake rates occurred in BSAW (Kruskal-Wallis, $p<0.001$ ), but there was no statistical difference between years in ACW (Kruskal-Wallis, $0.05<p<0.10$; Table 3).

Oxygen uptake rates underestimated total sediment metabolism in areas where sulfate reduction rates were 
Table 1. Hydrographic measurements and oxygen uptake rates for stations occupied during Cruises 59, 73, 74, 85 and 87 (hydrographic data for Cruises 74 and 85 from McRoy \& Tripp 1986, 1987). Rates are for duplicate experiments except where standard deviation (SD) is blank, indicating only one sediment core was measured. Other blanks in table indicate no data

\begin{tabular}{|c|c|c|c|c|c|c|}
\hline \multirow[t]{2}{*}{ Station } & \multirow{2}{*}{$\begin{array}{c}\text { Bottom } \\
\text { temp. } \\
\left({ }^{\circ} \mathrm{C}\right)\end{array}$} & \multirow{2}{*}{$\begin{array}{c}\text { Bottom } \\
\text { salinity } \\
(\%)(\%)\end{array}$} & \multirow[t]{2}{*}{$\begin{array}{l}\text { Bottom } \\
\text { sigma-t }\end{array}$} & \multirow{2}{*}{$\begin{array}{l}\text { Depth } \\
\text { (m) }\end{array}$} & \multicolumn{2}{|c|}{$\begin{array}{l}\text { Sediment oxygen uptake rates } \\
\qquad\left(\mathrm{mmol} \mathrm{O}_{2} \mathrm{~m}^{-2} \mathrm{~d}^{-1}\right)\end{array}$} \\
\hline & & & & & Mean & $\mathrm{SD}$ \\
\hline 59071 & -0.24 & 33.229 & 26.69 & 20 & 12.62 & - \\
\hline 59081 & -0.68 & 33.412 & 26.85 & 25 & 22.12 & 4.46 \\
\hline 59082 & -0.03 & 33.269 & 26.71 & 30 & 31.07 & 16.89 \\
\hline 59083 & -0.46 & 33.368 & 26.81 & 31 & 23.86 & 1.85 \\
\hline 59084 & -0.33 & 33.257 & 26.71 & 30 & 17.62 & 0.74 \\
\hline 59085 & -0.67 & 33.311 & 26.77 & 28 & 9.46 & 0.00 \\
\hline 59086 & -0.07 & 33.399 & 26.82 & 26 & 9.93 & 1.27 \\
\hline 59088 & 4.19 & 33.179 & 26.32 & 23 & - & - \\
\hline 59108 & -0.16 & 33.183 & 26.65 & 36 & - & - \\
\hline 59120 & -0.21 & 32.750 & 26.30 & 47 & 45.62 & 3.71 \\
\hline 59121 & 0.82 & 32.635 & 26.15 & 50 & 26.25 & 9.54 \\
\hline 59123 & 0.07 & 33.030 & 26.51 & 49 & 18.62 & 4.82 \\
\hline 59132 & 0.90 & 32.309 & 25.89 & 31 & - & - \\
\hline 73002 & 1.89 & 32.168 & 25.71 & 26 & 15.74 & - \\
\hline 73011 & 0.31 & 32.656 & 26.20 & 45 & 23.76 & 6.29 \\
\hline 73018 & 0.71 & 32.646 & 26.17 & 42 & 28.56 & - \\
\hline 73019 & 0.65 & 32.580 & 26.12 & 46 & 2.04 & - \\
\hline 73023 & - & - & - & 42 & 1.75 & 0.93 \\
\hline 73024 & - & - & - & 44 & 15.91 & 7.67 \\
\hline 73027 & 1.25 & - & - & 40 & 21.08 & - \\
\hline 73028 & 1.16 & 32.756 & 26.23 & 46 & 15.38 & 0.27 \\
\hline 73029 & 0.16 & 32.604 & 26.16 & 47 & 8.42 & - \\
\hline 73030 & 0.72 & 32.559 & 26.10 & 49 & 19.31 & 11.82 \\
\hline 73038 & 1.42 & 32.837 & 26.28 & 47 & 16.63 & - \\
\hline 73058 & 0.88 & 32.432 & 25.99 & 28 & 18.01 & - \\
\hline 73071 & 1.69 & 32.357 & 25.88 & 42 & 41.60 & - \\
\hline 73075 & 1.12 & 32.779 & 26.25 & 43 & 16.23 & 0.37 \\
\hline 73081 & 1.42 & 32.840 & 26.28 & 42 & 11.18 & 0.64 \\
\hline 73104 & 1.88 & 32.522 & 26.00 & 34 & 7.88 & 0.74 \\
\hline 73112 & 1.99 & 32.857 & 26.26 & 44 & 1.82 & 1.01 \\
\hline 73113 & 2.19 & 32.795 & 26.19 & 43 & 5.53 & - \\
\hline 73120 & 1.95 & 32.757 & 26.18 & 40 & 10.49 & 7.52 \\
\hline 73121 & 2.01 & 32.722 & 26.19 & 40 & 17.96 & 9.85 \\
\hline 73122 & 2.13 & 32.777 & 26.18 & 40 & 11.72 & - \\
\hline 74003 & 8.58 & 28.207 & 21.87 & 22 & 3.63 & - \\
\hline 74010 & 3.01 & 32.719 & 26.06 & 48 & 14.16 & 11.50 \\
\hline 74011 & 3.27 & 32.591 & 25.94 & 46 & 7.95 & 6.32 \\
\hline 74012 & 5.46 & 31.972 & 25.22 & 48 & 1.07 & 0.64 \\
\hline 74013 & 2.70 & 32.850 & 26.19 & 51 & 11.66 & 1.33 \\
\hline 74015 & 3.62 & 32.378 & 25.74 & 46 & 3.65 & 0.10 \\
\hline 74020 & 4.71 & 32.064 & 24.38 & 42 & 1.93 & 0.50 \\
\hline 74021 & 3.33 & 32.231 & 25.65 & 45 & 2.63 & 0.83 \\
\hline 74023 & 2.64 & 32.692 & 26.07 & 53 & 9.20 & 7.15 \\
\hline 73024 & 2.85 & 32.421 & 25.84 & 49 & 21.38 & 0.59 \\
\hline 74025 & 8.51 & 30.847 & 23.94 & 37 & 0.65 & 0.37 \\
\hline 74026 & 6.03 & 31.940 & 25.13 & 40 & 6.41 & 1.19 \\
\hline 74027 & 5.68 & 32.006 & 25.23 & 43 & 6.79 & - \\
\hline 74028 & 2.80 & 32.359 & - & 52 & 6.76 & 0.59 \\
\hline 74033 & 2.33 & 32.740 & 26.14 & 47 & 2.99 & 0.45 \\
\hline 85003 & 1.72 & 31.825 & 25.45 & 19 & 3.19 & - \\
\hline 85004 & 0.31 & 32.346 & 25.95 & 26 & 18.15 & 6.19 \\
\hline 85015 & 0.53 & 32.426 & 26.00 & 31 & 18.15 & 4.00 \\
\hline 85024 & 1.43 & 32.470 & 25.98 & 37 & 28.94 & - \\
\hline 85037 & 1.21 & 32.577 & 26.09 & 38 & 16.66 & 6.00 \\
\hline 85047 & 2.54 & 32.476 & 25.91 & 48 & 31.62 & - \\
\hline 85048 & 1.86 & 32.845 & 26.26 & 52 & 30.80 & 0.11 \\
\hline 85071 & 2.03 & 32.517 & 25.98 & 54 & 28.19 & 3.12 \\
\hline 85090 & 2.97 & 32.741 & 26.08 & 54 & 24.34 & 4.21 \\
\hline 85094 & 4.71 & 32.135 & 25.44 & 45 & 19.37 & 6.63 \\
\hline 85106 & 2.22 & 32.475 & 25.93 & 52 & 29.02 & 1.51 \\
\hline 85108 & 3.21 & 32.778 & 26.09 & 48 & 30.82 & 3.60 \\
\hline 87080 & 1.93 & 32.173 & 25.71 & 34 & 37.92 & - \\
\hline 87088 & 1.97 & 32.320 & 25.83 & 47 & 28.28 & 8.63 \\
\hline 87114 & 0.58 & 32.385 & 25.97 & 51 & 28.19 & 5.54 \\
\hline
\end{tabular}


Table 2. Comparison of mean sediment oxygen uptake and organic carbon mineralization rates for stations located in Bering Shelf-Anadyr Water and Alaska Coastal Water in the northern Bering and Chukchi Seas (including number of stations in parentheses and standard deviation, SD)

\begin{tabular}{|c|c|c|c|c|c|c|c|c|}
\hline \multirow[t]{3}{*}{ Location } & \multicolumn{4}{|c|}{ Bering Shelf-Anadyr Water } & \multicolumn{4}{|c|}{ Alaska Coastal Water } \\
\hline & \multicolumn{2}{|c|}{$\begin{array}{l}\text { Oxygen uptake rate } \\
\left(\mathrm{mmol} \mathrm{O} \mathrm{m}^{-2} \mathrm{~d}^{-1}\right)\end{array}$} & \multicolumn{2}{|c|}{$\begin{array}{l}\text { Organic carbon } \\
\text { mineralization rate } \\
\left(\mathrm{mmol} \mathrm{C} \mathrm{m}^{-2} \mathrm{~d}^{-1}\right)\end{array}$} & \multicolumn{2}{|c|}{$\begin{array}{l}\text { Oxygen uptake rate } \\
\left(\mathrm{mmol} \mathrm{O}_{2} \mathrm{~m}^{-2} \mathrm{~d}^{-1}\right)\end{array}$} & \multicolumn{2}{|c|}{$\begin{array}{l}\text { Organic carbon } \\
\text { mineralization rate } \\
\left(\mathrm{mmol} \mathrm{C} \mathrm{m}^{-2} \mathrm{~d}^{-1}\right)\end{array}$} \\
\hline & Mean & $\mathrm{SD}$ & Mean & $\mathrm{SD}$ & Mean & $\mathrm{SD}$ & Mean & $\mathrm{SD}$ \\
\hline $\begin{array}{l}\text { Northern } \\
\text { Bering Sea }\end{array}$ & $\begin{array}{c}19.85 \\
(34)\end{array}$ & 11.03 & $\begin{array}{c}20.10 \\
(34)\end{array}$ & 11.16 & $\begin{array}{c}11.80 \\
(8)\end{array}$ & 6.75 & $\begin{array}{c}12.10 \\
(8)\end{array}$ & 7.12 \\
\hline Chukchi Sea & $\begin{array}{c}16.82 \\
(11)\end{array}$ & 10.03 & $\begin{array}{c}20.57 \\
(11)\end{array}$ & 9.74 & $\begin{array}{c}5.58 \\
(8)\end{array}$ & 6.56 & $\begin{array}{l}6.03 \\
(8)\end{array}$ & 6.95 \\
\hline All stations & $\begin{array}{l}19.18 \\
(45)\end{array}$ & 10.76 & $\begin{array}{l}20.21 \\
(45)\end{array}$ & 10.72 & $\begin{array}{l}8.72 \\
(16)\end{array}$ & 7.15 & $\begin{array}{l}9.04 \\
(16)\end{array}$ & 7.34 \\
\hline
\end{tabular}

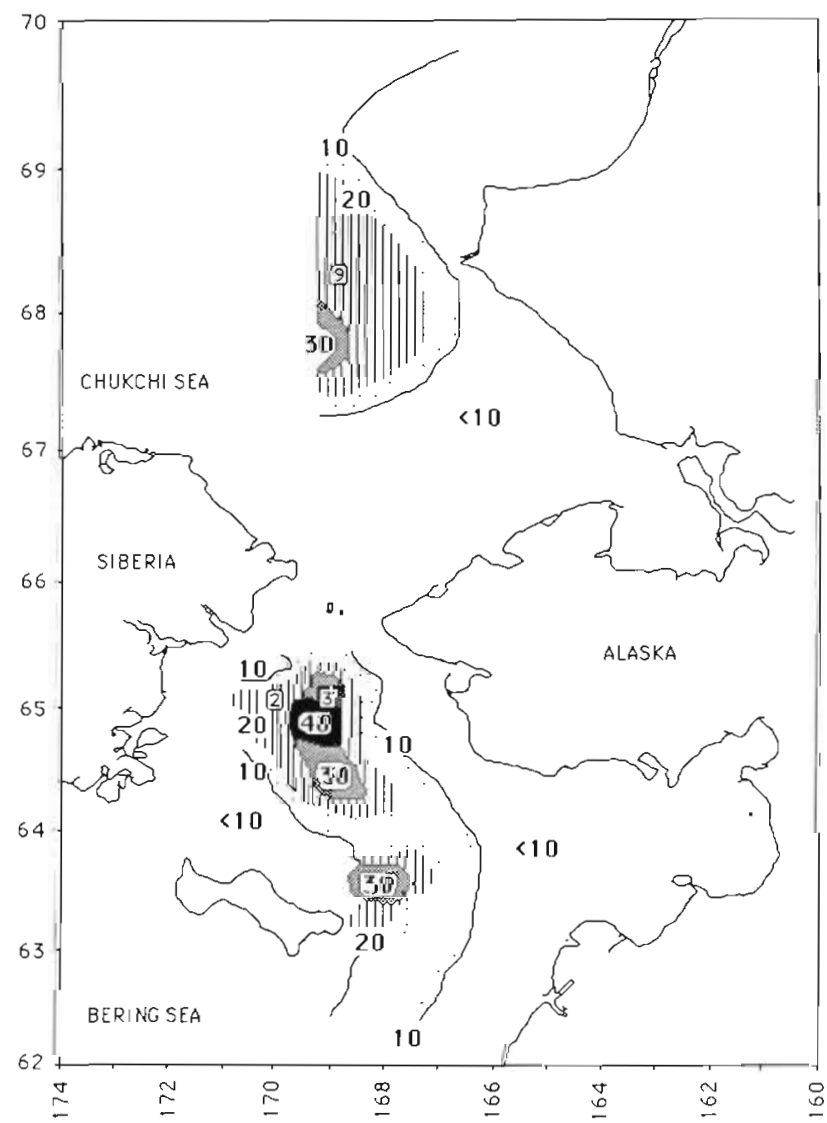

Fig. 3. Distribution of mean sediment oxygen uptake rates ( $\mathrm{mmol} \mathrm{O} \mathrm{m}^{-2} \mathrm{~d}^{-1}$ ) from July to September (1984 to 1986) in the northern Bering and Chukchi Seas. Boxed values are individual stations outside of contour interval

high (Table 4). Stations occupied in late August-early September (Cruise 74) under BSAW in the Chukchi Sea showed a marked increase in sulfate reduction rates ( 3.0 to $8.5 \mathrm{mmol} \mathrm{SO}=\mathrm{m}^{-2} \mathrm{~d}^{-1}$ ) resulting in a 30 to $68 \%$ increase in organic carbon mineralization (Table
4). This process was especially evident at two of these stations (74-011 and 74-023), where oxygen uptake rates only accounted for 32 to $33 \%$ of the organic carbon mineralization, the remainder of organic carbon mineralization being due to sulfate reduction. Sulfate reduction rates were used when available for other stations (Table 4 ), but were only 1.0 to $2.0 \mathrm{mmol} \mathrm{SO}=$ $\mathrm{m}^{-2} \mathrm{~d}^{-1}$ in the northern Bering Sea, resulting in only a 2 to $19 \%$ increase in organic carbon mineralization.

Five variables tested showed significant relationships with oxygen uptake (Pearson product-moment correlation; Table 5). High oxygen uptake rate was correlated to low bottom water temperature, high bottom water salinity, high bottom water sigma-t (seawater density), high bottom water chlorophyll $a$ and low sediment $\mathrm{C} / \mathrm{N}$ ratios, which are all indicative of BSAW (Grebmeier 1987).

\section{X-radiography}

Cores were examined by X-radiography to investigate the vertical structure of sediments in BSAW and ACW. Areas of highest bioturbation correspond to areas of high abundance and biomass in BSAW (Grebmeier et al. 1988, 1989). In the X-radiographs, densely packed ampeliscid amphipod tubes (Ampelisca macrocephala) appear as thin, white vertical tubes extending 8 to $9 \mathrm{~cm}$ into the sediments at a highly bioturbated station (59-123; Fig. 4); the large tube was occupied by an aorid amphipod (Lembos arcticus). Both amphipods are selective detritus feeders, but A. macrocephala is also considered a suspension feeder (Kanneworff 1965). The sediment type at this station is fine sand. A minimum estimate of increased surface area caused by the burrows is 200 to $300 \%$. Another BSAW station (74010) from the Chukchi Sea is dominated by selective detritus/suspension-feeding tellinid bivalves (Macoma 
Table 3. Mean sediment oxygen uptake rates from 1984 to 1986 for stations located in Bering Shelf-Anadyr Water and Alaska Coastal Water (including number of stations in parentheses and standard deviation, SD)

\begin{tabular}{|c|c|c|c|c|c|}
\hline \multirow[t]{2}{*}{ Year } & \multirow[t]{2}{*}{ Date } & \multicolumn{2}{|c|}{$\begin{array}{l}\text { Bering Shelf-Anadyr Water } \\
\text { Oxygen uptake rate } \\
\left(\mathrm{mmol} \mathrm{O}_{2} \mathrm{~m}^{-2} \mathrm{~d}^{-1}\right)\end{array}$} & \multicolumn{2}{|c|}{$\begin{array}{l}\text { Alaska Coastal Water } \\
\text { Oxygen uptake rate } \\
\left.\text { (mmol } \mathrm{O}_{2} \mathrm{~m}^{-2} \mathrm{~d}^{-1}\right)\end{array}$} \\
\hline & & Mean & SD & Mean & $\mathrm{SD}$ \\
\hline 1984 & $30 \mathrm{Jun}-10 \mathrm{Jul}$ & $24.72(8)$ & 10.15 & $9.70 \quad(2)$ & 0.33 \\
\hline 1985 & $\begin{array}{l}25 \text { Jul-10 Aug } \\
26 \text { Aug-9 Sep } \\
\text { All stations }\end{array}$ & $\begin{aligned} 15.31 & (18) \\
9.46 & (8) \\
13.51 & (26)\end{aligned}$ & $\begin{array}{l}9.72 \\
5.76 \\
9.01\end{array}$ & $\begin{aligned} 11.83 & (3) \\
3.60 & (7) \\
6.07 & (10)\end{aligned}$ & $\begin{array}{l}8.81 \\
3.74 \\
6.51\end{array}$ \\
\hline 1986 & $\begin{array}{l}11-26 \text { Jul } \\
14-24 \text { Aug } \\
\text { All stations }\end{array}$ & $\begin{array}{ll}27.55(8) \\
31.46(3) \\
28.62(11)\end{array}$ & $\begin{array}{l}4.95 \\
5.59 \\
5.17\end{array}$ & $\begin{array}{c}14.72(4) \\
- \\
14.72(4)\end{array}$ & $\begin{array}{l}7.71 \\
- \\
7.71\end{array}$ \\
\hline
\end{tabular}

Table 4. Oxygen uptake, sulfate reduction and organic carbon mineralization rates (sulfate reduction rates from Blackburn \& Henriksen 1986, Blackburn 1987a)

\begin{tabular}{|c|c|c|c|c|}
\hline Station $^{\alpha}$ & $\begin{array}{l}\text { Oygen } \\
\text { uptake }\end{array}$ & $\begin{array}{l}\text { (mmol m})^{-2} \\
\text { Sulfate } \\
\text { reduction }\end{array}$ & $\begin{array}{l}\text { Organic carbon } \\
\text { mineralization }\end{array}$ & $\begin{array}{c}\text { Aerobic } \\
\text { respiration } \\
(\%)\end{array}$ \\
\hline $74-010$ & 14.16 & 3.0 & 20.16 & 70 \\
\hline $74-011^{c}$ & $6.76^{c}$ & 7.0 & 20.76 & 33 \\
\hline $74-013$ & 11.66 & 0.5 & 12.66 & 92 \\
\hline $74-015$ & 3.65 & 0.8 & 5.25 & 70 \\
\hline $74-023^{c}$ & $7.82^{c}$ & 8.5 & 24.82 & 32 \\
\hline $85-015$ & 18.15 & 1.2 & 20.55 & 88 \\
\hline $85-024$ & 28.94 & 1.7 & 32.34 & 89 \\
\hline $85-037$ & 16.66 & 2.0 & 20.66 & 81 \\
\hline $85-048$ & 30.80 & 0.6 & 32.00 & 96 \\
\hline $85-071$ & 28.19 & 0.3 & 28.79 & 98 \\
\hline $85-090$ & 24.34 & 1.9 & 28.10 & 86 \\
\hline $85-094$ & 19.37 & 0.5 & 20.37 & 95 \\
\hline $85-106$ & 29.02 & 1.2 & 31.42 & 92 \\
\hline
\end{tabular}

Table 5. Pearson product-moment correlation statistics between sediment oxygen uptake rate and environmental parameters

\begin{tabular}{|lcc|}
\hline Environmental parameter & \multicolumn{2}{c}{$\begin{array}{c}\text { Sediment oxygen } \\
\text { uptake rate }\end{array}$} \\
(No. of observations) & Correlation coefficient & $\begin{array}{c}\text { Level of significance } \\
p\end{array}$ \\
\hline Bottom water temperature (64) & -0.393 & $<0.01$ \\
Bottom water salinity (63) & 0.263 & $0.01<p<0.05$ \\
Bottom water density (sigma-t; 62) & 0.324 & $0.01<p<0.05$ \\
Bottom water chlorophyll $a^{a}$ (66) & 0.240 & $0.01<p<0.05$ \\
Surface sediment C/N ratio (58) & -0.254 & $<p<0.05$ \\
a Bottom water chlorophyll a values from McRoy \& Tripp (1986, 1987) and Grebmeier (1987) & \\
b Surface sediment C/N ratios from Grebmeier (1987) & \\
\hline
\end{tabular}




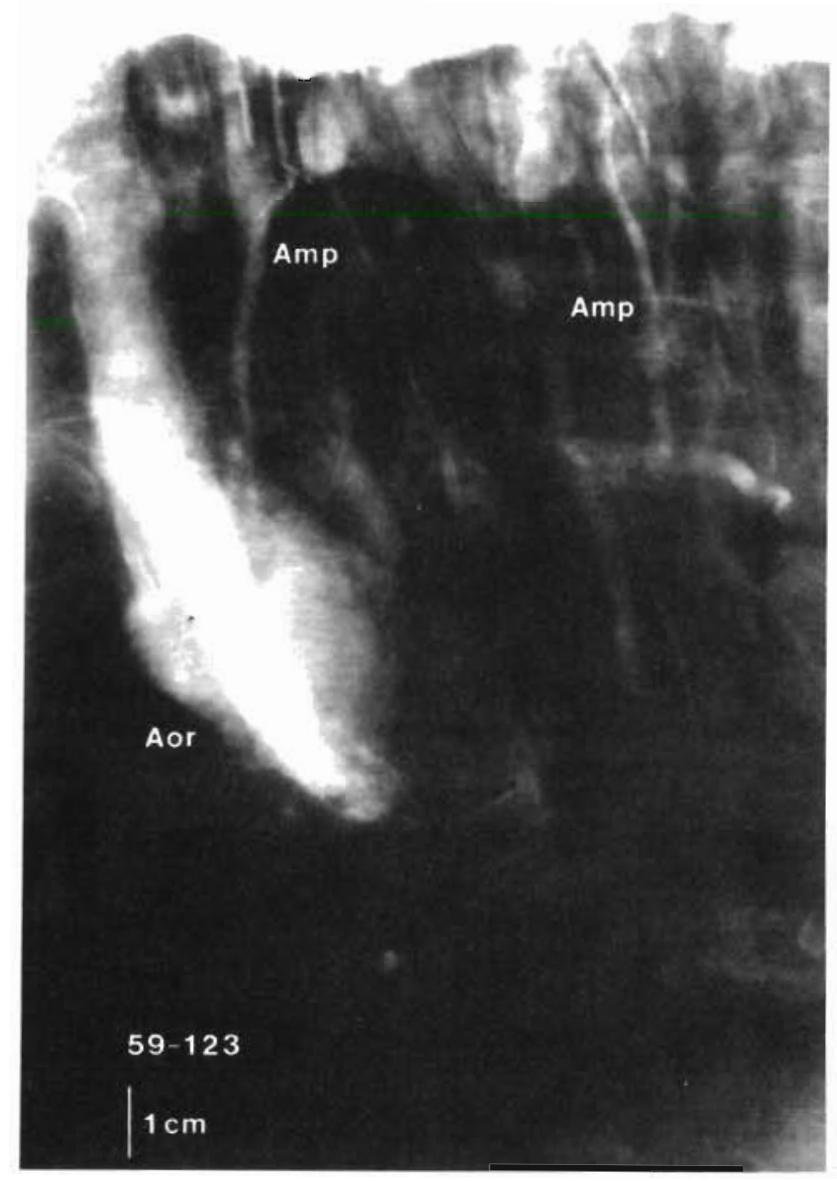

Fig. 4. X-radiograph of sediment core at Stn 59-123 showing infaunal bioturbation zone. Aor: F. Aoridae (Lembos arcticus): Amp: F. Ampeliscidae (Ampelisca macrocephala)

Calcarea; Fig. 5). The bioturbated zone extends $10 \mathrm{~cm}$ into the sediment, with empty bivalve shells occupying the sediments below this depth. Empty tellinid bivalve shells form a lag layer (an accumulation of shells with a larger surface area than surrounding sediment) at the base of this core. The sediment type at this station is fine sand, silt and clay.

Stations in ACW have less bioturbation than those in BSAW. The core from Stn 59-085 (Fig. 6) has one suspension-feeding styelid tunicate (Pelonaia corrugata) and a venerid bivalve (Liocyma fluctuosa). Sediments are primarily fine sand. The core from Stn 59-108 (Fig. 7) is composed of medium sand and is dominated by echinarachnid sand dollars (Echinarachnius parma). The zone of bioturbation extends to $6 \mathrm{~cm}$.

\section{Sediment core $\mathrm{C} / \mathrm{N}$ ratios}

Vertical profiles of $\mathrm{C} / \mathrm{N}$ ratios for $7 \mathrm{BSAW}$ and $4 \mathrm{ACW}$ sediment cores show a trend in the sediments under each water type, with lowest sediment $C / N$ ratios

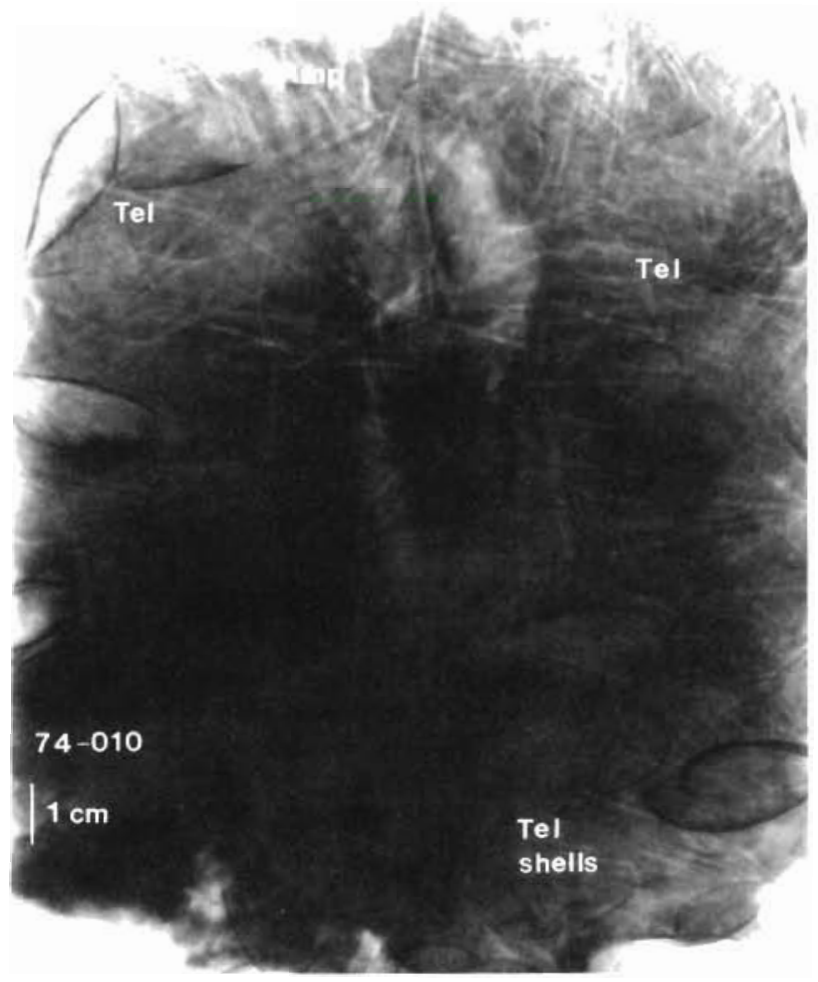

Fig. 5. X-radiograph of sediment core at Stn 74-010 showing infaunal bioturbation zone. Amp: F. Ampeliscidae (Byblis gaimard); Tel: F. Tellinidae (Macoma calcarea)

occurring in BSAW and highest sediment $\mathrm{C} / \mathrm{N}$ ratios occurring in ACW (Fig. 8). A bioturbated zone is distinguishable in these data by the vertical profile of similar $\mathrm{C} / \mathrm{N}$ ratios down to $7 \mathrm{~cm}$, with values rising below this zone.

\section{DISCUSSION}

Two factors, temperature and food supply, have a strong limiting influence on benthic metabolism (Graf et al. 1983, Hylleberg \& Riis-Vestergaard 1984), but they are often correlated, and therefore hard to separate. Davies (1975) and Wassman (1984) demonstrated that the amount of nutritious, labile organic material supplied to the benthos, rather than temperature, enhanced sediment oxygen uptake rates in fjord ecosystems. Pamatmat \& Banse (1969) found that variations in temperature could explain only $30 \%$ of the total variation in sediment oxygen uptake rates in Puget Sound, Washington. They proposed that this variance was due to seasonal changes in biological activity responding to a variable organic matter supply.

Both temperature and food supply influence benthic community structure in the northern Bering and Chuk- 


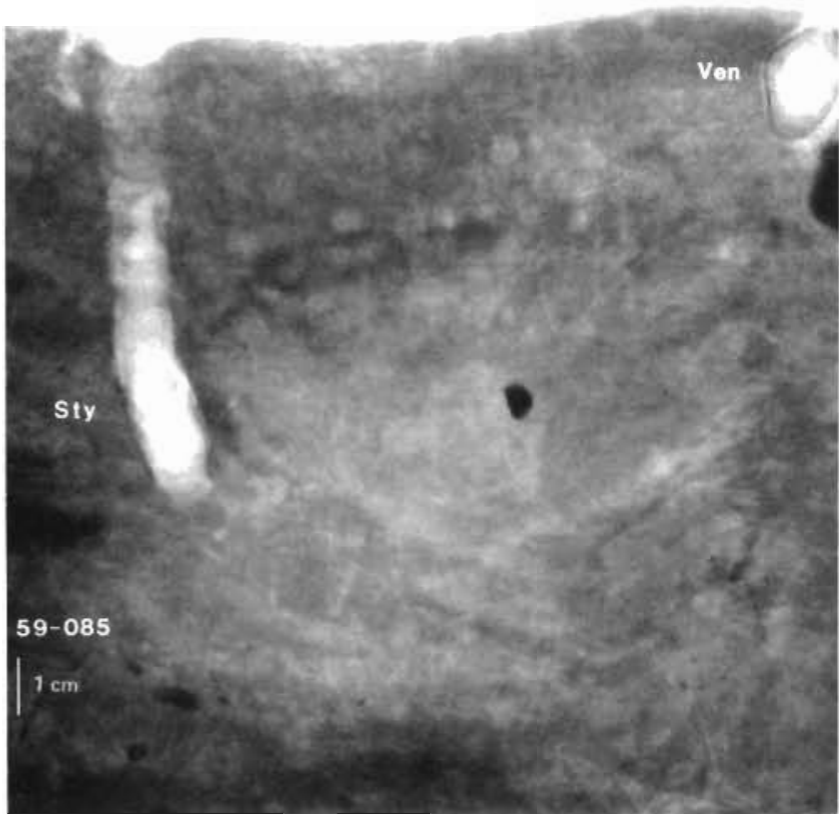

Fig. 6. X-radiograph of sediment core at Stn 59-085 showing Infaunal bioturbation zone. Sty F. Styelidae (Pelonaia corrugata); Ven: F. Veneridae (Liocyma fluctuosa)

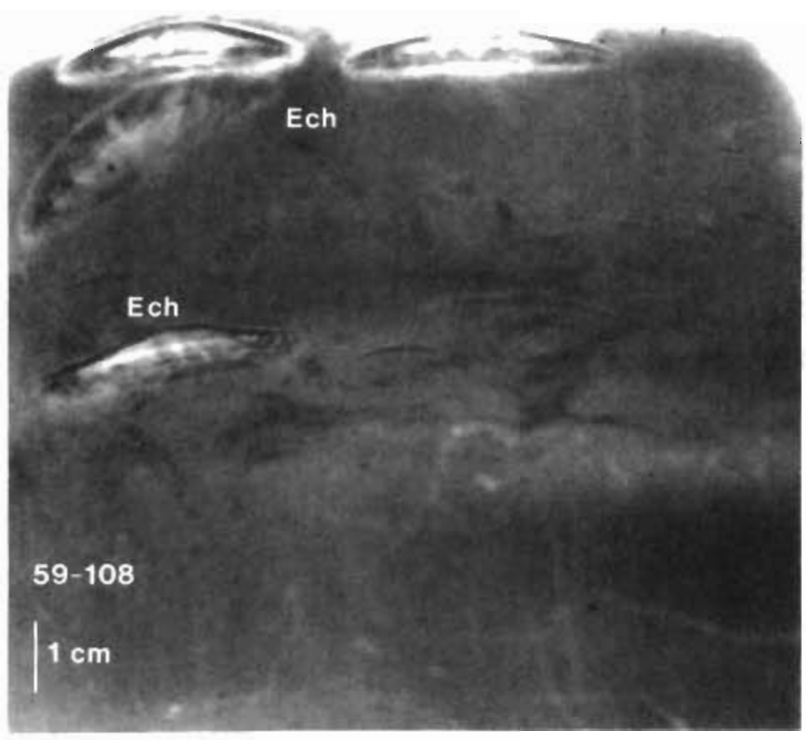

Fig. 7. X-radiograph of sediment core at Stn 59-108 showing infaunal bioturbation zone. Ech: F. Echinarachiniidae (Echinarachnius parma)

chi Seas (Grebmeier et al. 1989), with food supply determined to have the major influence on benthic biomass (Grebmeier et al. 1988). In the present study, the highest sediment oxygen uptake rate (mean $=19$
Sediment C/N retio (wt /wt)

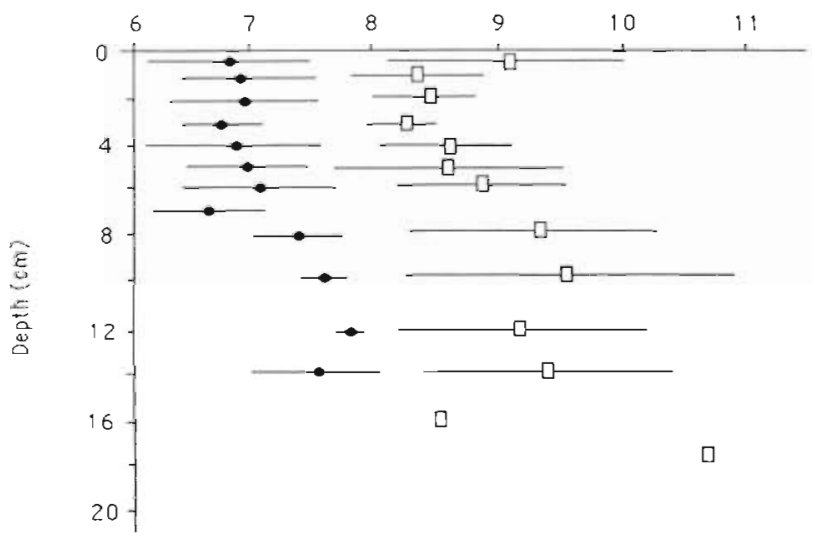

Fig. 8. Mean and range of $\mathrm{C} / \mathrm{N}$ ratios versus depth of sediments at stations located in Bering Shelf-Anadyr Water $(\bullet$ stations) and Alaska Coastal Water (0; 4 stations)

mmol $\mathrm{O}_{2} \mathrm{~m}^{-2} \mathrm{~d}^{-1}$ ) and organic carbon mineralization

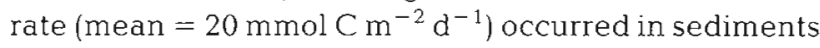
underlying BSAW, characterized by low temperatures and high primary production in the summer (Springer 1988, Walsh et al. 1988, Walsh et al. 1989). The measurement of higher metabolic rates in the lower temperature regime $\left(-1.0\right.$ to $\left.1.5^{\circ} \mathrm{C}\right)$ in $\mathrm{BSAW}$ indicates that bacterial and benthic faunal respiration in these northern waters may not be temperature limited. Comparing the 2 water types, a low mean benthic metabolism rate ( $9 \mathrm{mmol} \mathrm{O} \mathrm{m}^{-2} \mathrm{~d}^{-1}$; Table 1) occurred in the warmer ACW, where mean benthic biomass was also low $6 \mathrm{~g} \mathrm{C}$ $\mathrm{m}^{-2}$ ) compared to a high mean benthic metabolism rate (19 mmol $\mathrm{O}_{2} \mathrm{~m}^{-2} \mathrm{~d}^{-1}$; Table 2) and mean benthic biomass $\left(20 \mathrm{~g} \mathrm{C} \mathrm{m}^{-2}\right.$ ) in BSAW (Grebmeier et al. 1988). Although the data imply that the organic carbon flux to the benthos in BSAW was so much greater as to outweigh low temperature effects on benthic metabolism, further studies are needed on the effect of variable temperature regimes on benthic metabolism at the same sites in both BSAW and ACW to differentiate food supply from temperature effects.

Smetacek (1984) suggests that supply of organic matter to the sea floor in shallow coastal environments is a major factor influencing community structure, biomass and metabolism in the benthos; a conclusion supported in our studies (Grebmeier et al. 1988, 1989 this paper). On a global basis, sediment oxygen uptake in BSAW is within the expected range for inner shelf sediments, while the ACW sediment has oxygen uptake closer to those measured in the outer shelf and upper slope regions (Table 6). Inner shelf systems and, in this study, BSAW experience high water column primary production (Parsons et al. 1977, Jørgensen 1983, Springer 1988), along with high sediment oxygen uptake, indi- 
Table 6. Comparison of oxygen uptake rates in marine sediments from 5 depth zones and the areal coverage of these zones in the ocean (modified from Jørgensen 1983)

\begin{tabular}{lccc|}
\hline Zone & $\begin{array}{c}\text { Depth } \\
(\mathrm{m})\end{array}$ & $\begin{array}{c}\text { Area } \\
\left(10^{12} \mathrm{~m}^{2}\right)\end{array}$ & $\begin{array}{c}\text { Oxygen uptake rate } \\
\left(\mathrm{mmol}_{2} \mathrm{~m}^{-2} \mathrm{~d}^{-1}\right)\end{array}$ \\
\hline Inner shelf & $0-50$ & $13(4 \%)$ & 20 \\
Outer shelf & $50-200$ & $18(5 \%)$ & 10 \\
Upper slope & $200-1000$ & $15(4 \%)$ & 3 \\
Lower slope & $1000-4000$ & $106(29 \%)$ & 0.3 \\
Deep sea & $>4000$ & $208(58 \%)$ & 0.05 \\
\hline
\end{tabular}

cating that organic matter supply is a major regulating factor in sediment metabolism rates. In the study area, water column production is 5 to 6 times higher in BSAW than ACW (Springer 1988), which corresponds to a 3- to 4-fold greater benthic biomass in BSAW than ACW (Grebmeier et al. 1988). Differences in the quality and quantity of organic carbon reaching the sediment in these 2 water types suggest that food supply is a major regulating factor in benthic biomass (Grebmeier et al. 1988). The 2 to 3 times higher mean sediment oxygen uptake rate in BSAW compared to ACW supports the hypthesis of an enhanced food supply to the benthos in BSAW relative to the benthos under the less productive ACW.

The factors influencing sediment oxygen uptake may also influence the variability in rates between years. Although differences in sediment oxygen uptake were observed between years in BSAW, the relative difference within each year between BSAW and ACW was the same, that is, 2 to 3 times higher rates in BSAW compared to ACW. The lower 1985 mean oxygen uptake may be the result of reduced organic matter supply, although previous data, both surface sediment $\mathrm{C} / \mathrm{N}$ ratios and benthic biomass, indicated a seasonally reliable organic matter supply in these waters (Grebmeier et al. 1988). Another possibility is that samples were collected over a larger area, including stations underlying less productive regions of BSAW as well as in areas where organic matter accumulation in the sediments was low due to higher current velocities. Seasonal sampling at designated stations in each water type would clarify the influence of individual environmental parameters upon sediment oxygen uptake rates.

The significant correlations between oxygen uptake and 5 environmental variables (bottom water temperature, salinity, density, chlorophyll a concentration, and surface sediment $\mathrm{C} / \mathrm{N}$ ratio) suggest a relationship between oxygen uptake rates and the quantity and quality of organic matter reaching the sediment. Previous work on microbial respiration in Alaskan marine waters and sediments indicate no direct cause and effect relationship with temperature or salinity (Grif- fiths et al. 1984); a conclusion supported by this study. Griffiths et al. (1984) concluded that the quality of organic matter could best explain differences in microbial respiration rates. In the present study, the significant relationship between oxygen uptake and bottom chlorophyll a concentration indicates the importance of the quantity of organic matter, and the significant correlation with $\mathrm{C} / \mathrm{N}$ ratios in surface sediments reinforces the conclusion that the quality of organic matter also influences oxygen uptake rates. In combination, these variables indicate that a higher quantity and quality of organic matter reaches the benthos in BSAW than in $A C W$, thus resulting in higher sediment metabolism.

Total oxygen uptake was highest in the offshore central regions of the northern Bering and Chukchi Seas under BSAW (Fig. 3). These regions are characterized by relatively weak current flow (Creager \& McManus 1967, Nihoul 1986, Nihoul et al. 1986) and high phytoplankton biomass and primary production (Springer 1988), which is consistent with a high organic matter flux to the benthos. In addition, the highest oxygen uptake region in the northern Bering Sea coincides with the area of highest benthic biomass (Grebmeier et al. 1988). The bottom here is dominated by tube-dwelling ampeliscid amphipods Ampelisca macrocephala, which bind the sediments together through tube formation, and tellinid bivalves (Macoma calCarea; Grebmeier 1987 and unpubl.). The high oxygen uptake region off the northeast end of St Lawrence Island (Fig. 3) in fine-grain sediments was also dominated by these same species.

Most stations in ACW are characterized by low oxyen uptake ( $<10 \mathrm{mmol} \mathrm{O}_{2} \mathrm{~m}^{-2} \mathrm{~d}^{-1}$ ), except those occurring near the boundary with BSAW. Low oxygen uptake rates also occurred in BSAW just north of both Anadyr and Bering Straits. This could be the result of higher current velocities in this area (Coachman et al. 1975) that decrease the settling of organic material to the sediments. These sediments are characterized by rock, pebble, and gravel and are dominated by epifaunal communities (Stoker 1978). The low surface-to volume ratio and low organic content of these sedi- 
ments (Grebmeier 1987, Grebmeier et al. 1989) as well as reduced levels of bioturbation would be consistent with reduced sediment metabolism.

Aerobic respiration dominates organic carbon mineralization in both BSAW and ACW in the northern Bering Sea (Blackburn \& Henriksen 1986, Blackburn 1987b). However, organic carbon mineralization varies under BSAW in the Chukchi Sea depending on the amount of anaerobic respiration occurring there. Blackburn \& Henriksen (1986) and Blackburn (1987b) found that macrofaunal respiration accounted for 60 to $70 \%$ of the total aerobic mineralization in BSAW in the northern Bering Sea but only 5 to $50 \%$ in the Chukchi Sea. In $\mathrm{ACW}$, macrofaunal respiration accounted for 10 to $20 \%$ of the total aerobic mineralization. The remainder of aerobic mineralization was due to meio- and micro-fauna and bacteria. Using faunal oxygen uptake rates determined by $K$. Henriksen (unpubl.) for amphipods and bivalves (maintained in precombusted sediments) and faunal counts made at stations in our study (Grebmeier 1987), an estimate can be made for the dominant macrofaunal respiration component. This estimate indicates that dominant macrofauna account for $61 \%$ of the total sediment oxygen uptake rates measured in high amphipod areas in BSAW, which falls within the 60 to $70 \%$ range found by Blackburn \& Henriksen (1986) and Blackburn (1987b).

In the Chirikov Basin, ampeliscid amphipod tubes caused a 200 to $300 \%$ increase in sediment surface area at a representative station (59-123, Fig. 4). As a result, bioturbation must be important in BSAW sediments, thus enabling additional aerobic oxidation of organic material. The abundance and biomass of tubedwelling ampeliscid amphipods at this station were 4695 ind. $\mathrm{m}^{-2}$ and $10.7 \mathrm{~g} \mathrm{C} \mathrm{m}^{-2}$, respectively (Grebmeier 1987). Results (Table 4) show average aerobic respiration accounted for $\sim 88 \%$ of the total organic carbon mineralization in the Chirikov Basin for stations with high benthic biomass (85-024, -037, -048), which is comparable to $80 \%$ reported by Blackburn \& Henriksen (1986) and Blackburn (1987b). Ventilation of amphipod tubes by feeding currents and movement of animals allows oxygenated channels to extend 10 to 15 $\mathrm{cm}$ into the sediments (Fig. 4). Henriksen (1987) found that mats of Ampelisca spp. amphipods can influence uptake and release of nitrate from the sediments, as well as enhance ammonium output, depending on the overlying nutrient concentrations.

The station with the highest faunal standing stock occurred in the Chukchi Sea (Fig. 5) and was dominated by the tellinid bivalve Macoma calcarea (abundance = 548 ind $\mathrm{m}^{-2}$, biomass $=36.0 \mathrm{~g} \mathrm{C} \mathrm{m}^{-2}$; Grebmeier 1987 and unpubl.), which lives beneath the sediment surface and extends a siphon to the surface to feed on detritus. Byblis gaimardi, a detritus-feeding ampeliscid amphi- pod, was also dominant (abundance $=4408$ ind. $\mathrm{m}^{-2}$, biomass $=7.8 \mathrm{~g} \mathrm{C} \mathrm{m}^{-2}$; Grebmeier 1987 and unpubl.). although it builds a shallower, less permanent tube compared to the dominant ampeliscid amphipod (Ampelisca macrocephala) in the northern Bering Sea, and thus has less of an effect on altering sediment surface area available for aerobic respiration. Nevertheless, aerobic respiration accounted for $70 \%$ of the total carbon mineralization at this station, which indicates that the high standing stock is important. The increase in anaerobic metabolism at this station is associated with a higher sediment organic content $(1.2 \%)$ and finergrained sediments than found at stations in the Chirikov Basin (Grebmeier 1987, Grebmeier 1989). Areas of high anaerobic metabolism in the Chukchi Sea, such as Stn 74-023, are dominated by tellinid and nuculid bivalves (Grebmeier 1987). The ability of these bivalves to close their shells, thus reducing body exposure to high sulfide sediments, and an ability to feed and respire at the sediment surface, may enable them to compete better in an anoxic environment.

A representative station (59-085, Fig. 6) in ACW also had a bioturbated surface layer (6 to $8 \mathrm{~cm}$ ), although absolute abundance (1190 ind. $\mathrm{m}^{-2}$ ) and biomass (10.4 $\mathrm{g} \mathrm{C} \mathrm{m}^{-2}$ ) were low compared to BSAW stations (Grebmeier 1987, Grebmeier et al. 1989, and unpubl.). Styelid tunicates Pelonaia corrugata and sternaspid polychaetes Sternaspis scutata occurred at Stn 59-085, with the dominant fauna being sand dollars Echinarachnius parma (abundance $=230$ ind. $\mathrm{m}^{-2}$, biomass $=4.6 \mathrm{~g} \mathrm{C} \mathrm{m}^{-2}$, Grebmeier 1987 and unpubl.) E. parma was also dominant (abundance $=160$ ind. $\mathrm{m}^{-2}$, biomass $=0.2 \mathrm{~g} \mathrm{C} \mathrm{m}^{-2}$ ) at Stn 59-108 (Fig. 7) in ACW (Grebmeier 1987 and unpubl.). The sand dollar E. parma is an indicator of hydrodynamic stresses (tidal action) in the Bay of Fundy (Wildish \& Peer 1983) which can create impoverished benthic communities. Although tides are minimal in the northern Bering and Chukchi Seas (Pearson et al. 1981, Kowalik \& Matthews 1982), faster currents can occur where E. parma is dominant (Coachman et al. 1975), and may be responsible for the abundance of E. parma to the exclusion of other fauna (Grebmeier et al. 1989). However, at stations where E. parma is dominant in both BSAW and ACW, their abundance values are similar but their biomass values are at least 3 to 4 times greater in BSAW than ACW (Grebmeier 1987, Grebmeier et al. 1988). Therefore, although hydrodynamic stresses may influence species composition, food supply regulates benthic biomass. Low primary producion and organic carbon supply to the benthos not only limits benthic biomass (Grebmeier et al. 1988), but our study indicates food supply is the regulating factor limiting benthic metabolism in ACW in spite of high bottom water temperatures and low to moderate bioturbation. 
In summary, benthic carbon cycling in the northern Bering and Chukchi Seas was influenced by the quantity and quality of organic matter available to the benthos. Highest oxygen uptake rates occurred in BSAW in both basin regions of the northern Bering and Chukchi Seas, indicating a high organic matter flux to the benthos. In addition, the high numbers of macrofauna under portions of BSAW, which enhance bioturbation levels, and the high rate of organic carbon mineralization in the sediments, reflect high benthic food supply to the benthos. We conclude that the low sediment oxygen uptake in $\mathrm{ACW}$ is consistent with less organic matter supply to these sediments.

Acknowledgements. We thank the following people for assist ance and discussions during the study: $T \mathrm{H}$. Blackburn, $\mathrm{K}$ Henriksen, S. Henrichs, L. Cooper, W Reeburgh, and H Feder. In addition, 3 anonymous reviewers provided valuable comments that improved the manuscript. Technical assistance was provided by D. Boisseau (shipboard) and Dr J. Beckley DVM (X-radiography). Logistical and financial support were provided through the ISHTAR project (NSF-DPP-84-05286) and the University of Alaska Fairbanks (Institute of Marine Science, Vice-Chancellor for Research and Advanced Study, and the Department of Marine Science and Limnology). Additional shiptime was generously provided by Dr George L. Hunt, Jr, University of Califomia Irvine. We also extend our appreciation to the Captain and crew of the RV 'Alpha Helix' for their assistance.

\section{LITERATURE CITED}

Aller, R. C. (1980). Relationships of tube-dwelling benthos with sediment and overlying water chemistry. In: Tenore, K. R., Coull, B. C. (eds.) Marine benthic dynamics. University of South Carolina, Columbia, p. 285-308

Aller, R. C. (1982). The effects of macrobenthos on chemical properties of marine sediment and overlying water. In: McCall, P. L., Teveresz, M. J. S. (eds.) Animal-sediment relations. Plenum Press, New York, p. 53-102

Aller, R. C., Yingst, J. Y (1978). Biogeochemistry of tubedwellings: a study of the sedentary polychaete Amphitrite ornata (Leidy). J. mar. Res. 36: 201-254

Blackburn, T. H. (1987a). IV. Nutrient regeneration processes. In: 1986 ISHTAR Progress Report, VoI. I, Component C. Organic matter production and degradation on the shelf of the North Bering/Chukchi Shelves, Inst. Mar. Sci., Univ. Alaska, Fairbanks, p. 183-210

Blackburn, T H. (1987b). Microbial food webs in sediments. In: Sleigh, M. A. (ed.) Microbes in the sea. Ellis Horwood, Chichester, p. 39-58

Blackburn, T H., Henriksen, K (1986). III. Mineralization of sediment organic matter. In: ISHTAR 1985 Progress Report, Vol. I. Component C. Organic matter production and degradation on the shelf of the North Bering/Chukchi Shelves, Inst. Mar. Sci., Univ. Alaska, Fairbanks, p. 178-189

BrainPower, Inc. (1985). StatView ${ }^{T M}$. The graphics statistics utility for the MacIntosh ${ }^{T M}$ Calabasas, California

Coachman, L. K. (1987). Advection and mixing on the BeringChukchi Shelves. In: ISHTAR 1986 Progress Report, Vol. I, Component A. Advection and mixing of coastal water on high latitude shelves. Inst. Mar. Sci., Univ. Alaska, Fairbanks, p. 1-42

Coachman, L. K., Aagaard, K., Tripp, R. B. (1975). Bering Strait: the regional oceanography. Univ. Washington Press, Seattle

Conover, W. J. (1980). Practical nonparametric statistics. John Wiley \& Sons, New York

Creager, J. S., McManus, D. A. (1967). Geology of the floor of Bering and Chukchi Seas - American studies. In: Hopkins, D. M. (ed.) The Bering Land Bridge. Standord University Press, Stanford, p. 7-31

Davies, J. M. (1975). Energy flow through the benthos of a Scottish Sea Loch. Mar. Biol. 31: 353-362

Davies, J. M. Payne, P. (1984). Supply of organic matter to the sediment in the northern North Sea during a spring phytoplankton bloom. Mar. Biol. 78: 315-324

Deuser, W. G., Ross, E. H. (1980). Seasonal changes in the flux of organic carbon in the deep Sargasso Sea. Nature, Lond. 283: $364-365$

Deuser, W. G., Ross, E. H., Anderson, R. F. (1981). Seasonality in the supply of sediment to the deep Sargasso Sea and implications for the rapid transfer of matter to the deep ocean. Deep Sea Res. 28A(5): 495-505

Emerson, C. W., Minchinton, T. E., Grant, J. (1988). Population structure, biomass, and respiration of Mya arsenaria L. on temperate sandflat. J. exp. mar. Biol. Ecol. 115: 99-111

Eppley, R. W., Peterson, B. J. (1979). Particulate organic matter flux and planktonic new production in the deep ocean. Nature, Lond. 282: 677-680

Fauchald, K., Jumars, P. A. (1979). The diet of worms: a study of polychaete feeding guilds. Oceanogr. mar. Biol. A. Rev. 17: 193-284

Goldhaber, M. B., Aller, R. C., Cockran, J. K., Rosenfeld, J. K., Martens, C. S., Berner, R. A. (1977). Sulfate reduction, diffusion, and bioturbation in Long Island Sound sediments: report of the FOAM group. Am. J. Sci. 277: 193-237

Graf, G., Bengtsson, W., Diesner, U., Schulz, R., Theede, H. (1982). Benthic response to sedimentation of a spring phytoplankton bloom: process and budget. Mar. Biol. 67: 201-208

Graf, G., Schulz, R., Peinert, R., Meyer-Reil, L. A. (1983). Benthic response to sedimentation events during autumn to spring at a shallow-water station in the Western Kiel Bight. I. Analysis of processes on a community level. Mar. Biol. 77: 235-246

Gray, J. S. (1981). The ecology of marine sediments. Cambridge University Press, New York

Grebmeier, J. M. (1987). The ecology of benthic carbon cycling in the northern Bering and Chukchi Seas. Ph. D. dissertation, Univ. Alaska, Fairbanks

Grebmeier, J. M., Feder, H. M., McRoy, C. P. (1989). Pelagicbenthic coupling on the shelf of the northern Bering and Chukchi Seas. II. Benthic community structure. Mar. Ecol. Prog. Ser. 51. 253-268

Grebmeier, J. M., McRoy, C. P., Feder, H. M. (1988). Pelagicbenthic coupling on the shelf of the northern Bering and Chukchi Seas. I. Food supply and benthic biomass. Mar Ecol. Prog. Ser, 48: 57-67

Griffiths, R. P., Caldwell, B. A, Morita, R. V (1984). Observations on microbial percent respiration values in arctic and subarctic marine waters and sediments. Microb. Ecol. 10: $151-164$

Hargrave, B. T (1969). Similarity of oxygen uptake by benthic communities. Limnol. Oceanogr 14: 801-805

Hargrave, B. I (1973). Coupling carbon flow through some pelagic and benthic communities. J. Fish. Res. Bd Can. 30 $1317-1326$

Henriksen, K. (1987). V Mineralization of sediment organic matter. In: 1986 ISHTAR Progress Report, Vol. I, Component $C$. Organic matter production and degradation on the 
shelf of the North Bering/Chukchi Shelves. Inst. Mar. Sci.. Univ. Alaska, Fairbanks, p. 211-255

Hylleberg, J., Henriksen, K. (1980). The central role of bioturbation in sediment mineralization and element re-cycling. Ophelia, Suppl. 1. 1-16

Hylleberg, J., Riis-Vestergaard, H. (1984). Marine environments: the fate of detritus. Akademisk Forlag, Copenhagen

Jorgensen, B. B. (1982). Mineralization of organic matter in the sea bed - the role of sulphate reduction. Nature, Lond. 296: $643-645$

Jorgensen, B. B. (1983). Processes at the sediment-water interface. In: Bolin, B., Cook, R. (eds.) The major biogeochemical cycles and their interactions, SCOPE 21. Wiley, New York, p. 477--509

Kanneworff, E. (1965). Life cycle, food, and growth of the amphipod Ampelisca macrocephala Liljeborg from the Oresund. Ophelia 2: 305-318

Kemp, W. M., Boynton, W. R. (1981). External and internal factors regulating metabolic rates of an estuarine benthic community. Oecologia (Berl.) 51: 19-27

Kowalik, Z., Matthews, J. M. (1982). The $\mathrm{M}_{2}$ tide in the Beaufort and Chukchi Seas. J. phys. Oceanogr. 12: 743-746

McRoy, C. P., Goering, J. J., Shiels, W. (1972). Studies in primary productivity in the eastern Bering Sea. In: Takenouti. A., et al. (eds.) Biological oceanography of the northern North Pacific Ocean. Motoda Commemorative Volume, Idemitsu Shoten, Tokyo, p. 199-216

McRoy, C. P., Tripp, R. B. (1986). ISHTAR Data Report No. 2. 1985 Hydrographic Data, STD, nutrients, \& chlorophyll. Inst. Mar. Sci., Univ. Alaska, Fairbanks

McRoy, C. P., Tripp, R. B. (1987). ISTAR Data Report No. 4. 1986 Hydrographic Data, STD, nutrients, \& chlorophyll. Inst. Mar. Sci., Univ. Alaska, Fairbanks

Mills, E. L. (1975). Benthic organisms and the structure of marine ecosystems. J. Fish. Res. Bd Can. 32: 1657-1663

Newrkla, P. (1983). Methods for measuring benthic community respiration rates. In: Gnaiger, E., Forstner, H. (eds.) Polarographic oxygen sensors. Springer-Verlag, Berlin, p. 274-284

Nihoul, J. C. J. (1986). Component A. Advection and mixing of coastal water on high latitude shelves. In: ISHTAR 1985 Progress Report, Vol. I, Component C. Organic matter production and degradation on the shelf of the North Bering/Chukchi Shelves, Inst. Mar. Sci., Univ. Alaska, Fairbanks, p. 95-103

Nihoul, J. C. J., Waleffe, F., Djenidi, S. (1986). A 3D-numerical model of the northern Bering Sea. Environmental Software 1: 76-81

Nixon, S. W. (1981). Remineralization and nutrient cycling in coastal marine ecosystems. In: Nielson, B. J., Cronin, L. E. (eds.) Estuaries and nutrients. Humana Press, Clifton, p. $111-138$

Nixon, S. W., Kelly, J. R., Furnas, B. N., Oviatt, C. A., Hale, S. S. (1980). Phosphorus regeneration and the metabolism of coastal bottom communities. In: Tenore, K. R., Coull, B. C. (eds.) Marine benthic dynamics. University of South Carolina Press, Columbia, p. 219-242

Pamatmat, M. M. (1971a). Oxygen consumption by the seabed. IV. Shipboard and laboratory experiments. Limnol. Oceanogr. 16: 536-550

Pamatmat, M. M. (1971b) Oxygen consumption by the seabed. VI. Seasonal cycle of chemical oxidation and respiration in Puget Sound. Int. Revue ges. Hydrobiol. 56: 769-793

Pamatmat, M. M. (1977). Benthic community metabolism: a review and assessment of present status and outlook. In:
Coull, B. B. (ed.) Ecology of marine benthos. Univ. South Carolina Press, Columbia, p. 89-111

Pamatmat, M. M., Banse, K. (1969). Oxygen consumption by the seabed. II. In situ measurements to a depth of $180 \mathrm{~m}$. Limnol. Oceanogr. 14: 250-259

Parsons, T. R. K., Takahashi, M., Hargrave, B. T (1977). Biological oceanographic processes, 2nd edn. Pergamon Press, Oxford

Patching, J. W., Raine, R. C. T (1983). Benthic metabolism and the supply of organic material to the sea-bed. In: MacDonald, A. G., Priede, I. G. (eds.) Experimental biology at sea. Academic Press, New York, 311-345

Pearson, C. A., Mofjeld, H. O., Tripp, R. B. (1981). Tides of the eastern Bering Shelf. In: Calder, J. A. (ed.) The eastern Bering Sea shelf: oceanography and resources, Vol. 1, Univ. Washington Press, Seattle, p. 111-130

Rohlf, F. J., Sokal, R. R. (1969). Statistical tables. W. H. Freeman \& Co., San Francisco

Sambrotto, R. N., Goering, J. J., McRoy, C. P. (1984). Large yearly production of phytoplankton in the western Bering Strait. Science 225: 1147-1150

Schumacher, J. D., Aagaard, K., Pease, C. H., Tripp, R. B. (1983). Effects of a shelf polyna on flow and water properties in the northern Bering Sea. J. geophys. Res. 88(C5): 2723-2732

Smetacek, V. (1984). The supply of food to the benthos. In: Fasham, M. J. (ed.) Flows of energy and materials in marine ecosystems: theory and practice. Plenum Press, New York, p. 517-547

Smith, K. L., Jr (1973). Respiration of a sublittoral community. Ecology 54: 1065-1075

Smith, K. L., Jr (1978). Benthic community respiration in the N. W. Atlantic Ocean: in situ measurements from $40-5200 \mathrm{~m}$. Mar. Biol. 47: 337-347

Smith, K. L., Laver, M. B., Brown, N. O. (1983). Sediment community oxygen consumption and nutrient exchange in the central and eastern North Pacific. Limnol. Oceanogr 28 : 882-898

Springer, A. M. (1988). The paradox of pelagic food webs in the northern Bering Sea. Ph. D. dissertation, Univ. Alaska, Fairbanks

Stoker, S. W. (1978). Benthic invertebrate macrofauna of the eastern continental shelf of the Bering/Chukchi Seas. Ph. D. dissertation, Univ. Alaska, Fairbanks

Stoker, S. W. (1981). Benthic invertebrate macrofauna of the eastern Bering/Chukchi continental shelf. In: Hood, D. W., Calder, J. A. (eds.) The eastern Bering Sea shelf: oceanography and resources, Vol. 2, Univ. Washington Press, Seattle, p. 1069-1090

Suess, E. (1980). Particulate organic carbon flux in the oceanssurface productivity and oxygen utilization. Nature, Lond. 228: $160-263$

Walsh, J. J. and 12 co-authors (1988). The role of Bering Strait in the carbon/nitrogen fluxes of polar marine ecosystems. In: Rey, L., Alexander, V. (eds.) Marine living systems of the far North. E. J. Brill, Leiden (in press)

Walsh, J. J. and 20 co-authors (1989). Carbon and nitrogen cycling within the Bering/Chukchi Seas: source regions for organic matter effecting AOU demands of the Arctic Ocean. Prog. Oceanogr. (in press)

Wassman, P. (1984). Sedimentation and benthic mineralization of organic detritus in a Norwegian fjord. Mar. Biol. 83: 83-94

Wildish, D. J., Peer, D. (1983). Tidal current speed and production of benthic macrofauna in the lower Bay of Fundy. Can. J. Fish. Aquat. Sci. 40 (Suppl. 1): 309-321 